\title{
INVESTIGATON OF SEA LEVEL CHANGE ALONG THE BLACK SEA COAST FROM TIDE GAUGE AND SATELLITE ALTIMETRY
}

\author{
N. B. Avsar ${ }^{\text {a, }}$, S. H. Kutoglu ${ }^{\text {a }}$, S. Jin ${ }^{\text {a }}$, B. Erol ${ }^{\text {b }}$ \\ ${ }^{a}$ Bulent Ecevit University, Engineering Faculty, Dept. of Geomatics Engineering, 67100 Incivez, Zonguldak, Turkey - \\ nb_avsar@beun.edu.tr, kutogluh@hotmail.com,sg.jin@yahoo.com \\ b ITU, Civil Engineering Faculty, Dept. of Geomatics Engineering, 34469 Maslak, Istanbul, Turkey - bihter@itu.edu.tr
}

KEY WORDS: Black Sea, Coastal Sea Level Change, Linear Trend, Seasonal Variations, Satellite Altimetry, Tide Gauge

\begin{abstract}
:
In this study, we focus on sea level changes along the Black Sea coast. For this purpose, at same observation period the linear trends and the components of seasonal variations of sea level change are estimated at 12 tide gauge sites (Amasra, Igneada, Trabzon-II, Sinop, Sile, Poti, Batumi, Sevastopol, Tuapse, Varna, Bourgas, and Constantza) located along the Black Sea coast and available altimetric grid points closest to the tide gauge locations. The consistency of the results derived from both observations are investigated and interpreted. Furthermore, in order to compare the trends at the same location, it is interpolated from the trends obtained at the altimetric grid points in the defined neighbouring area with a diameter of $0.125^{\circ}$ using a weighted average interpolation algorithm at each tide gauge site. For some tide gauges such as Sevastopol, Varna, and Bourgas, it is very likely that the trend estimates are not reliable because the time-spans overlapping the altimeter period are too short. At Sile, the long-term change for the time series of both data types do not give statistically significant linear rates. However, when the sites have long-term records, a general agreement between the satellite altimetry and tide gauge time series is observed at Poti ( 20 years) and Tuapse ( 18 years). On the other hand, the difference of annual phase between satellite altimetry and tide gauge results is from $1.32^{\circ}$ to $71.48^{\circ}$.
\end{abstract}

\section{INTRODUCTION}

Sea level change is mostly due to changes in ocean heat content, and land ice mass balance, as well as water mass exchange between terrestrial reservoirs and oceans (Cazenave and Remy, 2011; Meyssignac and Cazenave, 2012). For almost two centuries, sea level change has been measured by tide gauges along coastlines (Dusto, 2014). On the other hand, since 1993, satellite altimetry has enabled monitoring of sea level changes at regional and global scales precisely (Fu and Cazenave, 2001). In this sense, to investigate sea level change, we need both good spatial resolution/coverage (like satellite altimetry data) and long time series (like tide gauges data) (Zhang and Church, 2012).

The tide gauge measures sea level change relative to a benchmark on the land whereas the satellite altimetry provides the absolute change with respect to the geocentric reference frame. Therefore, the tide gauge records also include the geophysical signals related to the land motion. Moreover, other factors; such as measurement noise, data gaps, data outliers, the different corrections applied to each of data, and the loss of quality in the satellite altimetry measurements near the coastlines induce a difference between the sea level time series obtained from the tide gauge records and satellite altimetry measurements. According to White at al. (2005), the observed difference is due to the sampling, both spatial and temporal. If there is also an instability in the altimeter instrument, a drift in the satellite instrument can be interpreted as a change in sea level (Fenoglio-Marc, 2002).
Sea level changes are usually not spatially uniform. In this study, sea level changes along the Black Sea coast is analysed from altimetry and tide gauge data, and the results are compared for both techniques.

In the Black Sea, having a limited interaction with the Atlantic Ocean, there are strong temporal mass variations owing to its wide drainage area covering a large part of Europe and Asia. The Black Sea level change is closely related to its hydrological balance (Vigo et al., 2005; Yildiz et al., 2011). Recent studies based on altimetry and tide gauge data have revealed the Black Sea level has risen (Avsar et al., 2015; Cazenave et al., 2002; Kubryakov and Stanichnyi, 2013; Vigo et al., 2005). Analysing satellite altimetry data, Avsar et al. (2015) reported an average trend of $3.16 \pm 0.77 \mathrm{~mm} /$ year over the Black Sea for the period 1993-2014. However, at coasts sea level change rate varies. Over shorter intervals the coastal sea level changes faster and over longer intervals slowly than the global mean (FenoglioMarc and Tel, 2010). We estimate the linear trends of the sea level time series for 12 tide gauge location along the Black Sea coast. In addition, we analyse the seasonal variations from both satellite altimetry and tide gauge data. Nevertheless, at least 50 year-records are needed to separate secular, decadal and interannual variations, and obtain more accurate trend estimations of sea level change (Douglas, 2001; Fenoglio-Marc and Tel, 2010). Unfortunately, over this long time records only few tide gauges along the Black Sea coast are available for the analysis.

\footnotetext{
* Corresponding author
} 


\section{DATA AND ANALYSIS}

\subsection{Satellite Altimetry Data}

The altimetry data set used for this study is daily sea level anomalies maps at $0.125^{\circ} \times 0.125^{\circ}$ grids provided by the French Archiving, Validation and Interpretation of the Satellite Oceanographic Data (AVISO) (http://www.aviso.altimetry.fr/en /data.html). This data set, a combined solution from the multi mission, covers nearly 22-year from January 1993 to December 2014. Necessary geophysical and atmospheric corrections are applied to the data set. For further details see AVISO web site.

There are 3249 altimetric grid points in the Black Sea when excluding the Sea of Azov. We choose the altimetry measurements at the closest points to the tide gauge sites as stated. Here, in order to compare the data from both observations, considering the time-spans of the tide gauge records, altimeter monthly time series are computed for the 12 sites.

\subsection{Tide Gauge Data}

For the present study, 7 tide gauge sites (Poti, Batumi, Sevastopol, Tuapse, Varna, Bourgas, and Constantza) located at along the Black Sea coast are chosen from the Permanent Service for Mean Sea Level (PSMSL) (http://www.psmsl.org /data/) and other 5 tide gauge (Amasra, Igneada, Trabzon-II, Sinop, and Sile) are from the Turkish Sea Level Monitoring System (TUDES) (http://www.hgk.msb.gov.tr/english/u-12turkish-sea-level-monitoring-system--tudes-.html). Figure 1 shows the locations of all data used in this study. An overview of the tide gauges is given in Table 1 .

The data set obtained from the PSMSL is monthly time series from the revised local reference data whereas the TUDES data are provided at 15-minute intervals in Turkish National Vertical control Network-1999 (TUDKA-99) datum. For the analysis, monthly averaged time series of the TUDES data are derived.

To compare to satellite altimetry data, we use the data after 1993 from the long-term tide gauge records. Some tide gauge time series include missing observations; therefore, the data gaps in the time series are eliminated.

\begin{tabular}{|l|c|c|c|}
\hline \multicolumn{1}{|c|}{$\begin{array}{c}\text { Tide gauge site } \\
\text { (Country) }\end{array}$} & \multicolumn{2}{|c|}{ Location } & \multirow{2}{*}{ Time-span } \\
\cline { 2 - 3 } & Latitude & Longitude & \\
\hline${ }^{1}$ Poti (Georgia) & $4210 \mathrm{~N}$ & $4141 \mathrm{E}$ & $1874-2013$ \\
${ }^{1}$ Batumi (Georgia) & $4138 \mathrm{~N}$ & $4142 \mathrm{E}$ & $1882-2013$ \\
${ }^{1}$ Sevastopol (Ukraine) & $4437 \mathrm{~N}$ & $3332 \mathrm{E}$ & $1910-1994$ \\
${ }^{1}$ Tuapse (Russia) & $4406 \mathrm{~N}$ & $3904 \mathrm{E}$ & $1917-2011$ \\
${ }^{1}$ Varna (Bulgaria) & $4311 \mathrm{~N}$ & $2755 \mathrm{E}$ & $1929-1996$ \\
${ }^{1}$ Bourgas (Bulgaria) & $4229 \mathrm{~N}$ & $2729 \mathrm{E}$ & $1929-1996$ \\
${ }^{1}$ Constantza (Romania) & $4410 \mathrm{~N}$ & $2840 \mathrm{E}$ & $1933-1997$ \\
${ }^{2}$ Amasra (Turkey) & $4145 \mathrm{~N}$ & $3224 \mathrm{E}$ & $2001-2014$ \\
${ }^{2}$ Igneada (Turkey) & $4153 \mathrm{~N}$ & $2801 \mathrm{E}$ & $2002-2014$ \\
${ }^{2}$ Trabzon-II (Turkey) & $4100 \mathrm{~N}$ & $3944 \mathrm{E}$ & $2002-2014$ \\
${ }^{2}$ Sinop (Turkey) & $4201 \mathrm{~N}$ & $3509 \mathrm{E}$ & $2005-2014$ \\
${ }^{2}$ Sile (Turkey) & $4111 \mathrm{~N}$ & $2937 \mathrm{E}$ & $2008-2014$ \\
\hline
\end{tabular}

Table 1. Tide gauge sites along the Black Sea coast $\left({ }^{1}\right.$ and ${ }^{2}$ refer the sites from PSMSL and TUDES respectively)

\subsection{Analysis and Results}

The sea level change time series are obtained from satellite altimetry and tide gauge. For example, Figure 2 illustrates the sea level changes at the Poti tide gauge site and the nearest corresponding point in the altimetry grids from January 1993 to December 2013. Sea level change time series have a strong seasonal signal and long term trend. So, we use a model including the annual, semi-annual components and a linear trend, and also given by Feng et al. (2012), to adjust the time series:

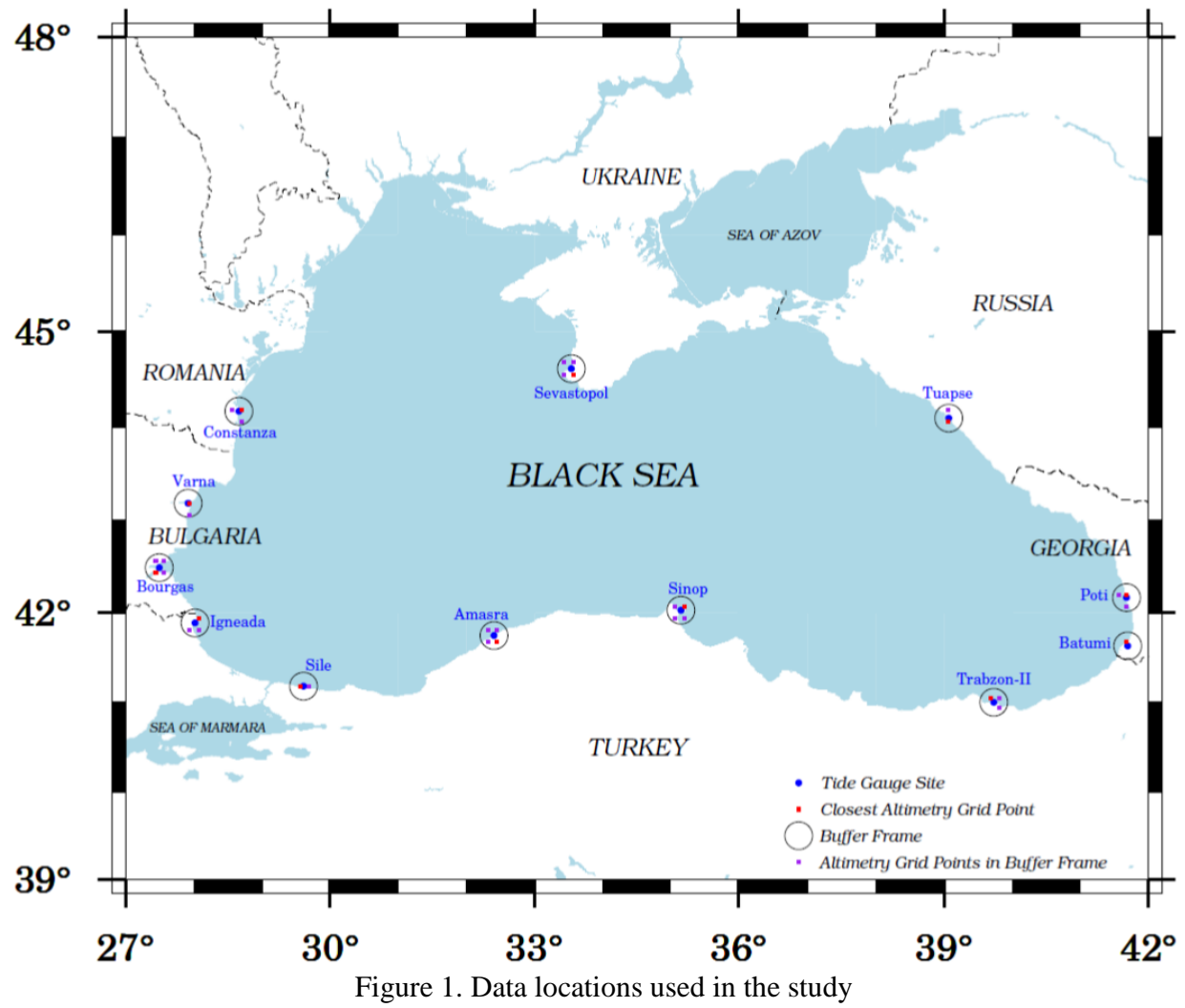




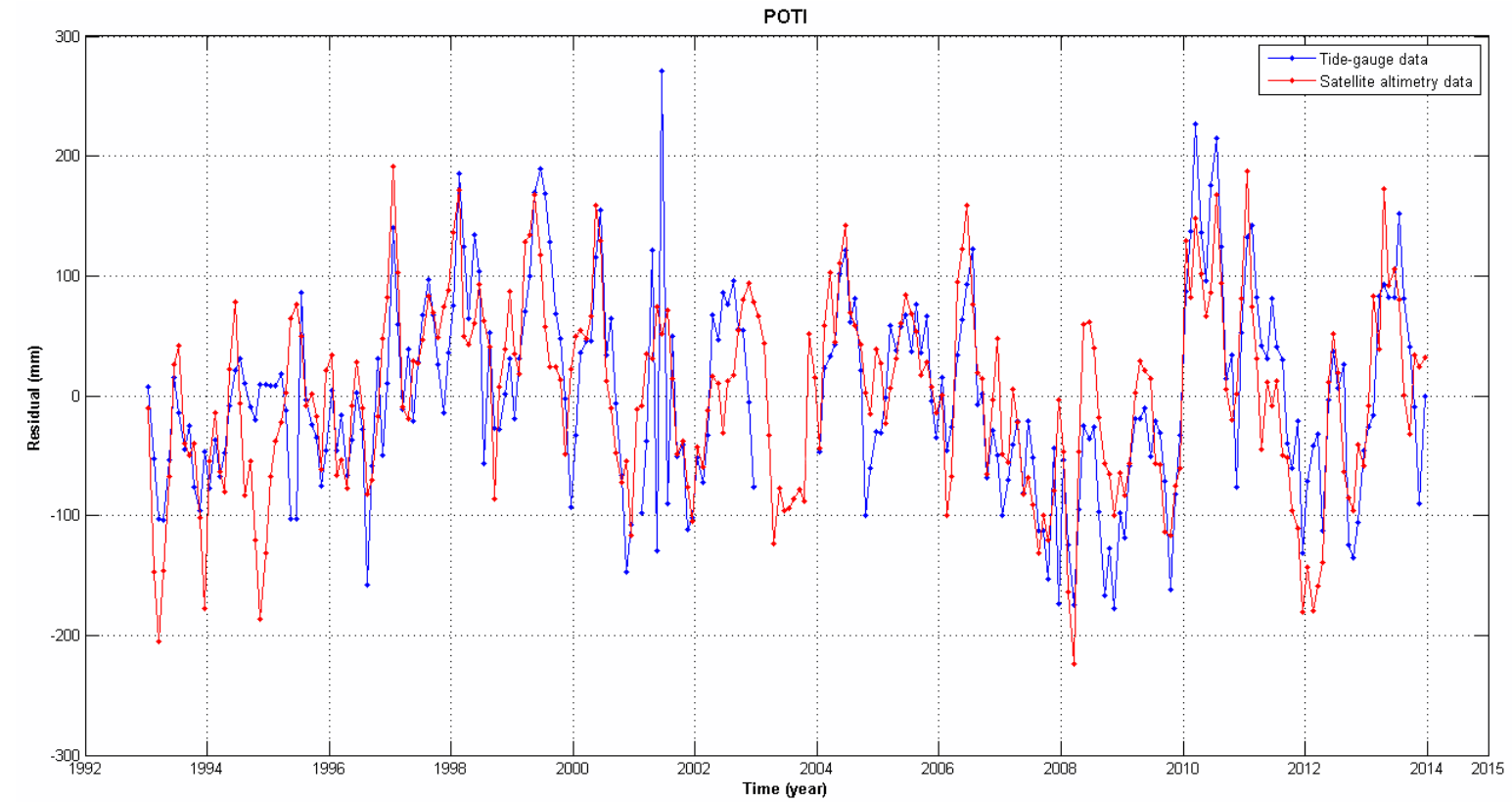

Figure 2. Detrended sea level change time series at Poti tide gauge site

$$
\begin{aligned}
\operatorname{MSL}(t) & =A_{a} \cdot \cos \left(\omega_{a} t-\phi_{a}\right)+A_{s a} \cdot \cos \left(\omega_{s a} t-\phi_{s a}\right) \\
& +B+C t+\varepsilon
\end{aligned}
$$

where $\quad M S L(t)=$ monthly mean sea level at $t$ time $A_{a}$ and $A_{s a}=$ annual and semi-annual amplitudes $\Phi_{a}$ and $\Phi_{s a}=$ annual and semi-annual phases $\omega_{a}$ and $\omega_{s a}=$ annual and semi-annual angular frequency

$B=$ monthly mean sea level at $t_{0}$ time

$C=$ long term trend

$\varepsilon=$ un-modelled residuals

Here, the least-squares method is used to fit the sea level change time series for each tide gauge. Generally, the time series of satellite altimetry and tide gauge show the same temporal behaviour in the sea level fluctuations at Poti site (Figure 2). For this site, the sea level trend computed from the tide gauge data is $4.00 \pm 0.85 \mathrm{~mm} /$ year that roughly corresponds to the trend value $3.38 \pm 0.82 \mathrm{~mm} /$ year obtained at the closest altimetric grid point to this site. Nevertheless, there are some discrepancies between the time series of two techniques, especially for the tide gauge sites with short time-spans. The distances between 12 tide gauge sites and the corresponding altimetric grid points, and the trend estimations are presented in Table 2.

To compare the trends estimated from satellite altimetry data at exact location of the tide gauge site, also a neighbouring area (buffer frame) with a diameter of $0.125^{\circ}$ around each tide gauge site is defined (Figure 1). In this way in order to derive the trend at the tide gauge site from altimetry data, it is utilized from the altimetric grid points in buffer frame. The trend values are computed using a weighted average interpolation algorithm at each tide gauge site. According to this algorithm, the weighting is based on the inverse of the square of the distance between the tide gauge site and the neighbour altimetric points. Here, the weighting and the boundary of the buffer are chosen empirically. However, interpolated trend values are not very different from the trends obtained at the closest altimetric grid points. So, these values are not included in this study.

\begin{tabular}{|l|l|l|l|l|}
\hline \multirow{2}{*}{ Tide gauge site } & $\begin{array}{l}\text { Distance between tide } \\
\text { gauge site and the } \\
\text { closest altimetric grid } \\
\text { point }(\mathrm{km})\end{array}$ & Time-span & \multicolumn{2}{|c|}{ Trend (mm/year) } \\
\cline { 3 - 5 } & 2.4 & $1993-2013$ & $3.38 \pm 0.82$ & $\begin{array}{l}\text { From satellite } \\
\text { altimetry data }\end{array}$ \\
Poti & 6.2 & $1993-2013$ & $3.86 \pm 0.83$ & $-5.00 \pm 0.85$ \\
Batumi & 6.8 & $1993-1994$ & $-7.35 \pm 16.78$ & $9.55 \pm 22.85$ \\
Sevastopol & 4.2 & $1993-2011$ & $3.19 \pm 0.95$ & $3.95 \pm 1.02$ \\
Tuapse & 2.4 & $1993-1996$ & $21.22 \pm 6.54$ & $37.94 \pm 10.87$ \\
Varna & 7.2 & $1993-1996$ & $19.42 \pm 7.04$ & $45.64 \pm 11.98$ \\
Bourgas & 3.3 & $1993-1997$ & $24.72 \pm 4.76$ & $14.46 \pm 5.93$ \\
Constantza & 7.9 & $2001-2012$ & $2.22 \pm 0.79$ & $-0.31 \pm 1.52$ \\
Amasra & 7.9 & $2002-2014$ & $2.02 \pm 1.69$ & $6.23 \pm 2.25$ \\
Igneada & 8.6 & $2002-2014$ & $-0.38 \pm 1.71$ & $2.26 \pm 2.06$ \\
Trabzon-II & 6.0 & $2005-2014$ & $6.85 \pm 2.65$ & $-0.02 \pm 3.16$ \\
Sinop & 5.5 & $2008-2014$ & $3.45 \pm 4.76$ & $4.54 \pm 5.54$ \\
Sile & Side gauge \\
\hline
\end{tabular}

Table 2. Trend of sea level changes at tide gauge sites from satellite altimetry and tide gauge data in common observation period 
The International Archives of the Photogrammetry, Remote Sensing and Spatial Information Sciences, Volume XL-1/W5, 2015 International Conference on Sensors \& Models in Remote Sensing \& Photogrammetry, 23-25 Nov 2015, Kish Island, Iran

\begin{tabular}{|l|l|l|l|l|l|l|l|l|}
\hline \multirow{2}{*}{$\begin{array}{l}\text { Tide gauge } \\
\text { site }\end{array}$} & \multicolumn{3}{|c|}{ From satellite altimetry data } & \multicolumn{3}{c|}{ From tide gauge data } \\
\cline { 2 - 8 } & $\begin{array}{l}\text { Annual } \\
(\mathrm{mm})\end{array}$ & \multicolumn{2}{|c|}{ Semi-annual } & \multicolumn{2}{c|}{ Annual } & \multicolumn{2}{c|}{ Semi-annual } \\
\cline { 2 - 9 } & Phase $\left(^{\circ}\right)$ & $\begin{array}{l}\text { Amplitude } \\
(\mathrm{mm})\end{array}$ & Phase $\left(^{\circ}\right)$ & $\begin{array}{l}\text { Amplitude } \\
(\mathrm{mm})\end{array}$ & Phase $\left(^{\circ}\right)$ & $\begin{array}{l}\text { Amplitude } \\
(\mathrm{mm})\end{array}$ & Phase $\left(^{\circ}\right)$ \\
Poti & $30.49 \pm 6.38$ & $-37.82 \pm 0.21$ & $23.65 \pm 6.38$ & $-12.98 \pm 0.27$ & $45.95 \pm 6.83$ & $-30.33 \pm 0.15$ & $17.21 \pm 6.84$ & $43.13 \pm 0.40$ \\
Batumi & $33.69 \pm 6.33$ & $-35.60 \pm 0.19$ & $24.30 \pm 6.33$ & $-16.17 \pm 0.26$ & $46.11 \pm 10.18$ & $35.88 \pm 0.22$ & $1.18 \pm 10.16$ & $37.68 \pm 8.60$ \\
Sevastopol & $31.53 \pm 6.12$ & $-76.24 \pm 0.19$ & $18.40 \pm 6.12$ & $-16.32 \pm 0.33$ & $71.56 \pm 9.23$ & $-29.08 \pm 0.13$ & $28.66 \pm 9.23$ & $-11.06 \pm 0.22$ \\
Varna & $41.29 \pm 6.17$ & $-74.24 \pm 0.15$ & $20.23 \pm 6.17$ & $-0.31 \pm 0.31$ & $55.63 \pm 6.82$ & $-42.99 \pm 0.12$ & $26.78 \pm 6.80$ & $18.66 \pm 0.25$ \\
Bourgas & $25.33 \pm 5.92$ & $-52.30 \pm 0.23$ & $15.62 \pm 5.92$ & $-23.67 \pm 0.38$ & $43.91 \pm 15.19$ & $-84.37 \pm 0.33$ & $17.47 \pm 15.09$ & $-37.93 \pm 0.82$ \\
Constantza & $27.95 \pm 5.75$ & $-47.05 \pm 0.24$ & $16.97 \pm 5.75$ & $-22.81 \pm 0.34$ & $71.88 \pm 4.83$ & $-52.56 \pm 0.26$ & $22.34 \pm 11.86$ & $-26.94 \pm 0.55$ \\
Amasra & $23.41 \pm \pm 6.13$ & $-53.31 \pm 0.26$ & $23.80 \pm 6.14$ & $-18.27 \pm 0.26$ & $27.11 \pm 6.69$ & $-61.39 \pm 0.24$ & $9.35 \pm 6.52$ & $-8.24 \pm 0.71$ \\
Igneada & $24.51 \pm 5.97$ & $-51.33 \pm 0.24$ & $13.78 \pm 5.94$ & $-10.20 \pm 0.43$ & $51.83 \pm 10.79$ & $-38.93 \pm 0.21$ & $22.41 \pm 10.80$ & $43.36 \pm 0.48$ \\
Trabzon-II & $27.28 \pm 6.10$ & $-48.95 \pm 0.22$ & $25.96 \pm 6.10$ & $2.26 \pm 0.23$ & $62.62 \pm 8.92$ & $-26.38 \pm 0.14$ & $27.28 \pm 8.95$ & $17.16 \pm 0.33$ \\
Sinop & $29.06 \pm 5.98$ & $-66.34 \pm 0.21$ & $30.48 \pm 3.80$ & $-11.78 \pm 0.25$ & $48.99 \pm 11.15$ & $-44.16 \pm 0.23$ & $29.49 \pm 11.17$ & $11.95 \pm 0.38$ \\
Sile & $19.47 \pm 6.02$ & $-62.79 \pm 0.31$ & $18.08 \pm 6.01$ & $-16.82 \pm 0.33$ & $62.74 \pm 12.66$ & $-51.00 \pm 0.20$ & $22.84 \pm 12.66$ & $48.96 \pm 0.55$ \\
\hline
\end{tabular}

Table 3. Seasonal components of satellite altimetry and tide gauge time series

As stated previously, the only difference between two observation data is the vertical land motion. If there are not a considerable land motion around tide gauge site, and also apart from the other error sources mentioned before, altimetry and tide gauge time series should exhibit fluctuations congruently. Here, for the sites having long-term records a general agreement between two time series is observed at Poti ( 20 years $)$ and Tuapse ( 18 years). However, the estimate for the linear slope of tide gauge time series at Batumi ( 20 years) is too poor due to 7-year gap of the time series. Unfortunately, for some tide gauges such as Sevastopol, Varna, and Bourgas, the time-spans overlapping the altimeter period are too short. Therefore, it is very likely that the linear trend estimates are not reliable for these stations. The trend revealed at the closest altimetric grid point to Trabzon-II is a value indistinguishable from zero within 1 sigma. Similarly, this case is valid for tide gauge time series at Amasra and Sinop. In association with short time-span at Sile, the linear rates of long-term change for the time series of both observation data are not statistically significant.

In Table 3, seasonal variations of the Black Sea level are analysed. Accordingly, the difference of annual phase between satellite altimetry and tide gauge results is from $1.32^{\circ}$ to $71.48^{\circ}$, with the maximum at Batumi. The annual cycles of sea level variations measured by the altimetry reach the maximum values almost a month later than the sea level variations obtained from tide gauge data.

Moreover, we calculate the correlation coefficients between two independent time series. The trends of tide-gauge and satellite altimetry time series are consistent with a correlation of 0.70 . The correlation of annual variations from two independent observation techniques is 0.43 in the annual phases that may be reasonable. However, there is a very weak linear correlation between two time series in the annual amplitudes. Figure 3(a)(c) show the correlations between satellite altimetry and tide gauge results.

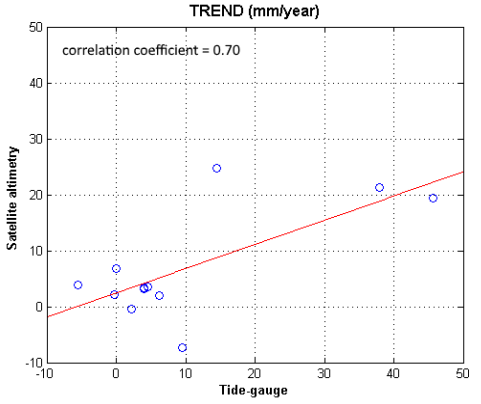

(a)

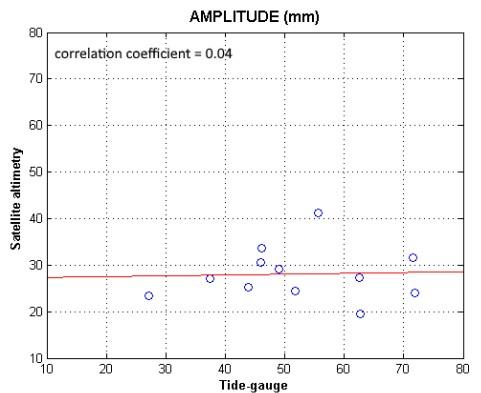

(b)

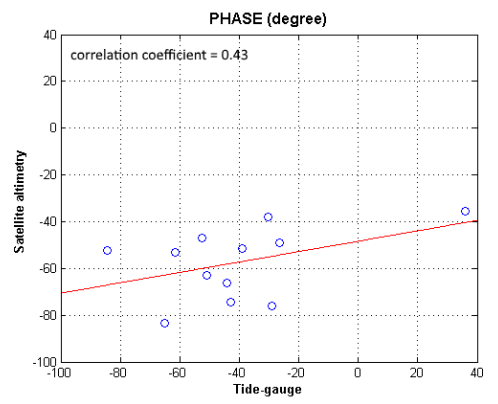

(c)

Figure 3. Correlation coefficients between satellite altimetry and tide gauge results for (a) trend, (b) amplitude, and (c) phase 


\section{CONCLUSIONS}

Sea level is a dynamical parameter related to climate change. The regional sea level changes mostly differ from the global mean value. In this study, coastal sea level change of the Black Sea is represented by data of 12 tide gauge selected from the PSMSL and the TUDES, and by the corresponding nearly colocated altimetric grid points. The altimetric points determined as the closest to the tide gauge sites can be as far as roughly 9.8 $\mathrm{km}$. When considering coastal geometry of each tide gauge, the distance may be regarded as a source of error, especially for seasonal and shorter variations.

The results point out that the trend estimations are sensitive to the length of data record. The observed difference between the rate from satellite altimetry and tide gauges may be related to inter-annual or shorter period variability of coastal sea level. Because in short records, trend estimations can be affect low frequency signals. In addition to that, the uncertainty owing to the fitting procedure is essential for accurate trend estimation.

For more accurate sea level change analysis, the data outliers should be detected and eliminated. The data gaps should also be taken into consideration.

Ignoring the other error sources, when focusing on the difference between the satellite altimetry and tide gauge data for the same observation period, the only difference would be actual vertical land motion. In next study, we will further investigate the effects of vertical motion on sea level change at each tide gauge site along the Black Sea coast.

\section{ACKNOWLEDGEMENTS}

We are grateful for the organizations that provided the data used in this study, including CNES AVISO, the Permanent Service for Mean Sea Level, and the General Command of Mapping (Turkey).

\section{REFERENCES}

Avsar, N.B., Kutoglu, S.H., Erol, B., Jin, S., 2015. Sea level changes in the Black Sea using satellite altimetry and tide-gauge observations. Proceedings of the $26^{\text {th }}$ IUGG General Assembly, June 22-July 2, Prague, Czech Republic.

Cazenave, A., Bonnefond, P.F., Mercier, F., Dominh, K., Toumazou, V, 2002. Sea level variations in the Mediterranean Sea and Black Sea from satellite altimetry and tide gauges. Glob. Planet. Change, 34, 59-86.

Cazenave, A., Remy, F., 2011. Sea level and climate: measurements and cause of changes. Interdisciplinary Rev.: Clim. Change, 2(5), pp. 647-662.

Douglas, B.C., 2001. Sea level change in the era of the recording tide gauge. In: Sea Level Rise, History and Consequences, B.C. Douglas, M.S. Kearney, and S.P. Leatherman, eds., International Geophysics Series, Vol. 75, Academic Press, pp. 37-64.

Dusto, A., 2014. NOAA Climate.gov science \& information for climate smart nation "Reading between the tides: 200 years of measuring global sea level" https://www.climate.gov/news features/climate-tech/reading-between-tides-200-years-measurin g-global-sea-level (2 May 2015).

Feng, G., Jin, S., Zhang, T., 2012. Coastal sea level changes in Europe from GPS, tide-gauge, satellite altimetry and GRACE, 1993-2011. Adv. Space Res., 51(2013), 1019-1028.

Fenolio-Marc, L., 2002. Long-term sea level change in the Mediterranean Sea from multi-mission satellite altimetry and tide gauges, Phys. Chem. Earth, 27, 1419-1431.

Fenoglio-Marc, L., Tel, E., 2010. Coastal and global sea level. J. Geodyn., 49, 151-160.

Fu, L.L., Cazenave, A., 2001. Satellite Altimetry and Earth Sciences: A Handbook of Techniques and Applications. Academic Press, San Diego, 463 pp.

Kubryakov, A.A., Stanichnyi, S.V., 2013. The Black Sea level trends from tide gauges and satellite altimetry. Russian Meteorol. Hydrol., 38(5), 329-333.

Meyssignac, B., Cazenave, A., 2012. Sea level: a review of present-day and recent-past changes and variability. J. Geodyn., 58, pp. 96-109.

Vigo, I., Garcia, D., Chao, B.F., 2005. Change of sea level trend in the Mediterranean and Black seas. J. Mar. Res., 63, pp. 10851100 .

White, N.J., Church, J.A., Gregory, J.M., 2005. Coastal and global averaged sea level rise for 1950 to 2000. Geophys. Res. Lett, 32, L01601.

Yildiz, H., Andersen, O.B., Simav, M., Kilicoglu, A., Lenk, O., 2011. Black sea annual and inter-annual water mass variations from space. J. Geod., 85(2), 119-127.

Zhang, X., Church, J.A., 2012. Sea level trends, interannual and decadal variability in the Pasific Ocean. Geophys. Res. Lett., 39 , L21701. 